\title{
7 Patterns in Foodgrain Consumption and Calorie Intake
}

\author{
GUUSH BERHANE, LINDEN MCBRIDE, \\ KIBROM TAFERE HIRFRFOT, \\ AND SENESHAW TAMIRU
}

The quality, quantity, and composition of food consumption are major determinants of the nutritional well-being of individuals, which has, in turn, important implications for individual and household-level health, productivity, and income. An analysis of food consumption patterns is essential to understanding and projecting domestic demand for agricultural products, as well as for the development of national policies to promote food security.

Food consumption patterns in Ethiopia are diverse, and, unlike in many other countries, no single crop dominates the national food basket (as, for example, rice does in most of East Asia, maize in Latin America, or cassava in Central Africa). The Ethiopian food basket consists of a wide variety of grains and other staples. However, the quantity, composition, and security of the average consumption basket varies by place of residence, agroecology, socioeconomic level, and livelihood strategy. Moreover, these consumption patterns have shifted over time.

This chapter presents analysis of spatial and temporal food consumption trends in Ethiopia with a focus on the six principal staples in the country: teff, wheat, maize, sorghum, barley, and enset (a root crop also known as "false banana"). A quick look at the nationally representative data used in this analysis shows that together these six staples make up much of the national food basket, supplying around 70 percent of total caloric intake (Table 7.1).

Given the high diversity in consumption patterns-see, for example, the differences in consumption of teff, maize, sorghum, and processed cereals by rural and urban households in Table 7.1-as well as the growth trends in production (see Chapter 3) and calorie consumption (discussed later), food security in Ethiopia has risen from the mid-1990s through 2004/05. However, significant vulnerabilities remain throughout the country, especially among poor households in the sparsely populated rural regions.

The data used in the analyses that follow come from the Household Income, Consumption, and Expenditure Surveys (HICES), conducted by the Ethiopian Central Statistical Agency (CSA), and the Livelihoods Integration Unit (LIU), provided by the Government of Ethiopia Disaster Prevention and 
TABLE 7.1 Per capita calorie contributions of food items, by rural-urban place of residence, 2004/05

\begin{tabular}{|c|c|c|c|c|}
\hline \multirow[b]{2}{*}{ Food item } & \multicolumn{3}{|c|}{ Calories per capita per day } & \multirow{2}{*}{$\begin{array}{l}\text { Percent } \\
\text { of total }\end{array}$} \\
\hline & Urban & Rural & National & \\
\hline \multicolumn{5}{|l|}{ Cereals } \\
\hline Teff & 601.70 & 196.69 & 254.13 & 11 \\
\hline Wheat & 200.59 & 309.79 & 294.30 & 13 \\
\hline Maize & 107.53 & 435.99 & 389.40 & 17 \\
\hline Sorghum & 94.72 & 366.21 & 327.70 & 14 \\
\hline Barley & 38.16 & 144.58 & 129.48 & 6 \\
\hline Other cereals & 25.21 & 53.29 & 49.31 & 2 \\
\hline Processed cereals & 195.15 & 17.10 & 42.35 & 2 \\
\hline Enset, kocho, and bulla & 27.18 & 215.15 & 188.49 & 8 \\
\hline Total cereals and enset & $1,290.24$ & $1,738.79$ & $1,675.17$ & 72 \\
\hline \multicolumn{5}{|l|}{ Noncereals } \\
\hline Pulses & 123.94 & 167.06 & 160.95 & 7 \\
\hline Oilseeds & 2.49 & 5.43 & 5.01 & 0 \\
\hline Animal products & 65.43 & 58.07 & 59.12 & 3 \\
\hline Oils and fats & 145.18 & 31.91 & 47.98 & 2 \\
\hline Vegetables and fruits & 60.78 & 59.43 & 59.62 & 3 \\
\hline Pepper & 6.89 & 3.57 & 4.04 & 0 \\
\hline Coffee, tea, and chat & 30.62 & 42.72 & 41.01 & 2 \\
\hline Root crops & 72.36 & 124.52 & 117.12 & 5 \\
\hline Sugar and salt & 93.54 & 51.67 & 57.61 & 3 \\
\hline Other foods & 96.47 & 103.28 & 102.31 & 4 \\
\hline Total noncereals & 697.70 & 647.66 & 654.77 & 28 \\
\hline Total & $1,987.96$ & $2,386.46$ & $2,329.94$ & 100 \\
\hline
\end{tabular}

SOURCE: Authors' calculations based on HICES (2004/05).

Preparedness Agency. The HICES, conducted roughly every five years since 1995/96, provide a large, nationally representative dataset with detailed information on consumption quantities and expenditures. ${ }^{1}$ The LIU data were collected between 2006 and 2009 via the Household Economy Approach, an analytical framework that assesses livelihoods and how they might respond to environmental and economic shocks. ${ }^{2}$ The LIU data were scaled up with population figures from the 2008 Ethiopia Census to provide national estimates. Unlike the HICES, which offer nationally representative data based on inter-

1. The data are representative of all urban and rural areas of Ethiopia with the following exceptions: all zones of the Gambella region, three nonsedentary zones of the Afar region, and six nonsedentary zones of the Somali region.

2. For more information, see The Practitioners Guide to HEA at www.feg-consulting.com/ resource/practitioners-guide-to-hea. 
views conducted with approximately 22,600 households, the LIU offers little more than stylized facts regarding household livelihood and consumption patterns. However, these stylized facts provide valuable insights into the consumption patterns of otherwise difficult-to-survey populations - the pastoral and agropastoral households that comprise 10 percent of the rural population-so we rely on them here to provide a more complete and disaggregated look at consumption in Ethiopia.

After a brief overview of general consumption trends and income and price demand elasticities, this chapter will take a closer look at spatial consumption patterns, disaggregating household consumption by place of residence, agroecology, income, and livelihood. The chapter then observes how these trends have changed over time and concludes with a discussion about how these trends relate not only to current and future food security but also to national agricultural growth and development policies.

\section{General Trends in Food Consumption in Ethiopia}

Food consumption in Ethiopia has been on the rise since the mid-1990s; meanwhile, the share of food consumption expenditures in the average household budget has fallen. The HICES datasets show that food consumption expenditures declined from 60 percent in 1995/96 to 56 percent in 2004/05 (Ethiopia, MoFED 2008), while per capita income (expenditure) rose by 16 percent over the same period. ${ }^{3}$ These findings are consistent with Engel's Law, which dictates that as household incomes rise, the share of household income spent on food falls. However, the decline in food expenditure varies slightly across rural-urban locations. Figure 7.1 presents the density of per capita food expenditure by rural-urban location. Although the national food expenditure pattern clearly follows the rural expenditure distribution, urban expenditure is significantly higher than rural.

The pattern in Figure 7.1 conceals considerable heterogeneity across income levels in both rural and urban areas. Figure 7.2 presents a nonparametric Engel curve that captures this heterogeneity, depicting per capita total expenditure against per capita food expenditure. As expected, the share spent on food falls as household per capita total expenditure rises. However, Figure 7.2 shows that among those at the lower end of the income distribution, rural households spend more on food, and the decrease in food share as income rises is smaller for rural than for urban households. Because the Engel effect is more pronounced in urban than in rural households at all income levels, we can expect the gap between food expenditures in rural versus urban areas to decline as incomes rise.

3. Throughout this chapter, income estimates have been calculated by aggregating household expenditure data from the HICES. In describing household welfare status, income and expenditure are used interchangeably. 
FIGURE 7.1 Nonparametric regression estimates of per capita food expenditure, 2004/05

Epanechnikov density

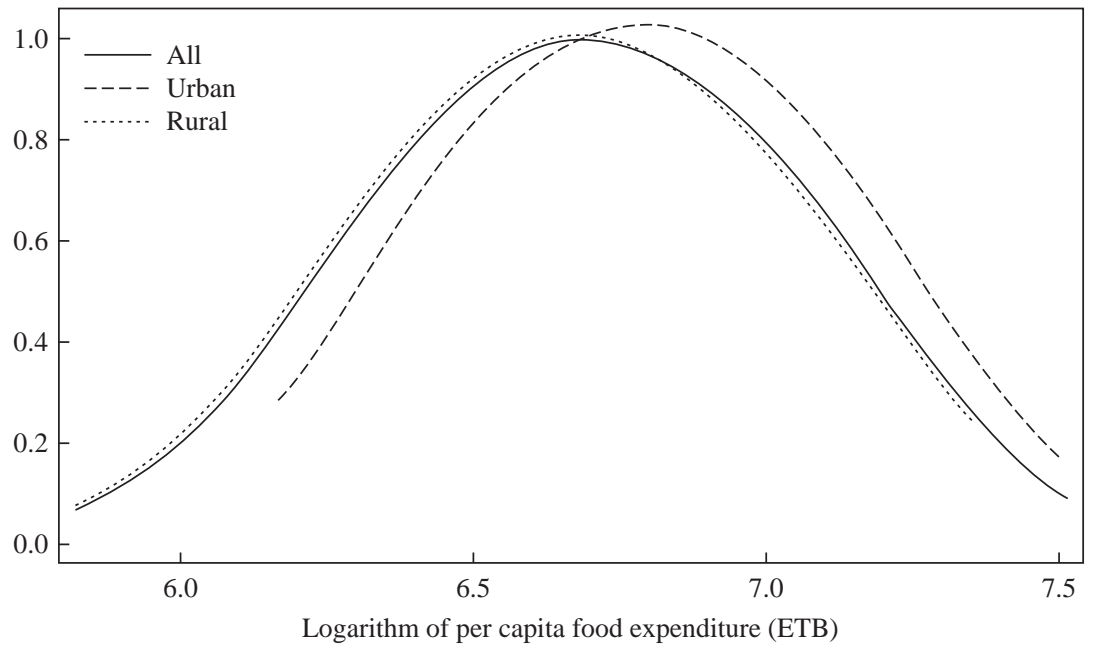

SOURCE: Authors' calculations based on HICES (2004/05).

NOTES: Bandwidth $=0.3$. The Epanechnikov density indicates the distribution of population according to per capita consumption. ETB = Ethiopian birr. The natural $\log$ of 6 corresponds to a value of ETB 403; the natural $\log$ of 7 corresponds to a value of ETB 1,097; the natural $\log$ of 8 corresponds to a value of ETB 2,981; the natural $\log$ of 9 corresponds to a value of ETB 8,103.

FIGURE 7.2 Nonparametric Engel curve, 2004/05

Food expenditure share (percent)

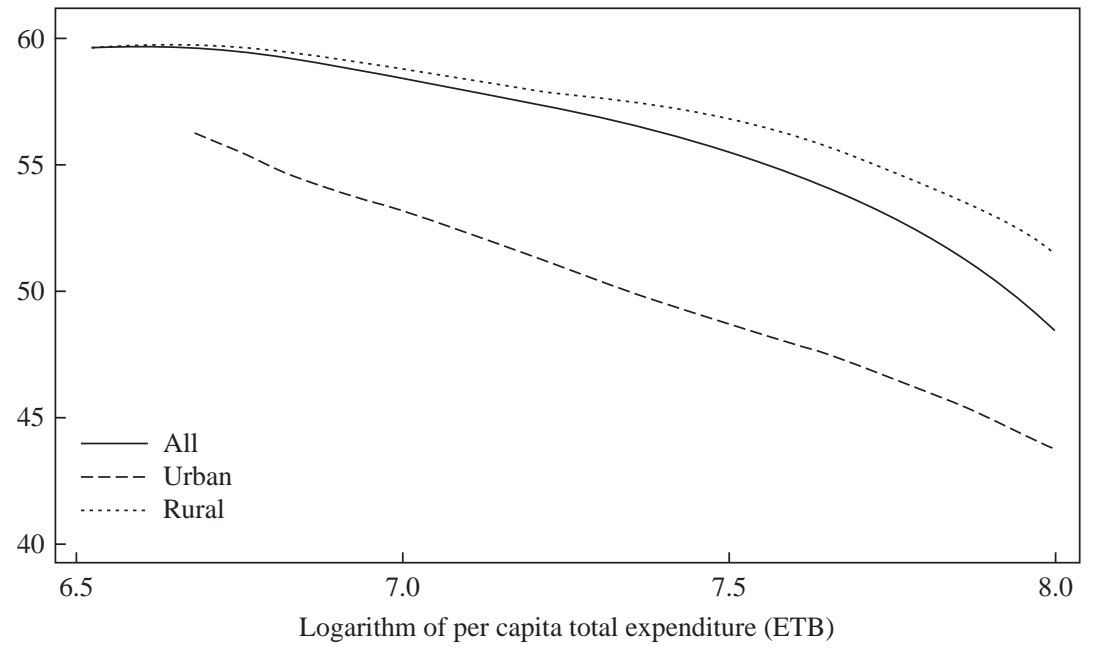

SOURCE: Authors' calculations based on HICES (2004/05).

NOTES: Nonparametric regressions estimates; bandwidth $=0.25$. ETB $=$ Ethiopian birr. 
As might be expected from these figures, consumption patterns throughout the country are responsive to changes in income and price (Table 7.2). Estimated income and price elasticities of demand for the 2004/05 HICES dataset are presented in Table 7.2 (Tafere et al. 2009). ${ }^{4}$ These elasticity estimates reflect rural-urban preference and expenditure differences among major food items. All major foodgrains, with the exception of sorghum in urban areas, are normal goods and sensitive to income changes in rural and urban areas. Teff boasts the greatest income elasticity among cereals in both rural and urban areas: a 1 percent increase in income increases teff demand by more than 1 percent. In fact, in rural areas, teff is a luxury foodgrain, consumed at festivities or offered to special guests and, in some instances, available only to older family members. Wheat and maize appear to be important foodgrains in both urban and rural areas; a greater price elasticity of both grains is observed among urban residents compared to rural ones. As reflected by the differing budget shares and income elasticities of demand, sorghum plays an important role in rural diets but is an inferior good among urban residents. However, cross-price elasticity estimates suggest that sorghum is complementary to teff in urban areas (Tafere et al. 2009); this finding is likely due to the common practice among poorer urban residents of mixing sorghum with teff to make injera, Ethiopia's main national dish. In general, all major foodgrains have close to unitary ownprice elasticities in both locations.

The remainder of this chapter is devoted to analysis of the variations in consumption patterns of the six major staples (teff, wheat, maize, sorghum, barley, and the root crop enset) across spatial and temporal parameters.

\section{Spatial Trends in Consumption}

Due to extensive geographical and productive heterogeneity and poor market linkages, household consumption patterns of the major staple crops are spatially heterogeneous. For example, teff is largely consumed in urban and semiurban Ethiopia; maize and sorghum are major lowland staples but are also consumed minimally in urban areas. Wheat has become an important staple throughout the country in recent decades, in part due to large-scale wheat food aid shipments over time that have encouraged wheat consumption. Barley is consumed mostly in the colder highlands and belg growing areas, but only to a limited extent. ${ }^{5}$ Enset is consumed primarily in the highland areas of the Southern Nations, Nationali-

4. Using the same dataset, Tafere et al. (2009) estimate a demand system of 10 equations (9 equations in their linear model) and apply an iterative feasible generalized nonlinear least squares estimation procedure to both the linear almost ideal demand system and the quadratic almost ideal demand system models.

5. The Ethiopian production season is divided into two periods of productivity: the more productive meher season and the less productive belg season. 
TABLE 7.2 Budget shares and own price and income (expenditure) elasticities of demand for selected food items, by rural-urban place of residence, 2004/05

\begin{tabular}{|c|c|c|c|c|c|c|}
\hline \multirow[b]{2}{*}{ Food item } & \multicolumn{3}{|c|}{ Urban } & \multicolumn{3}{|c|}{ Rural } \\
\hline & $\begin{array}{c}\text { Percent } \\
\text { of total } \\
\text { budget } \\
\text { spent }\end{array}$ & $\begin{array}{c}\text { Own } \\
\text { price } \\
\text { elasticity } \\
\text { of demand }\end{array}$ & $\begin{array}{l}\text { Income } \\
\text { elasticity } \\
\text { of demand }\end{array}$ & $\begin{array}{c}\text { Percent } \\
\text { of total } \\
\text { budget } \\
\text { spent }\end{array}$ & $\begin{array}{c}\text { Own } \\
\text { price } \\
\text { elasticity } \\
\text { of demand }\end{array}$ & $\begin{array}{c}\text { Income } \\
\text { elasticity } \\
\text { of demand }\end{array}$ \\
\hline Teff & 16.7 & -0.92 & 1.10 & 7.5 & -0.92 & 1.20 \\
\hline Wheat & 4.9 & -1.00 & 0.78 & 9.6 & -0.94 & 1.19 \\
\hline Maize & 1.9 & -0.93 & 0.37 & 9.9 & -0.70 & 0.82 \\
\hline Sorghum & 1.8 & -0.93 & -0.36 & 9.3 & -0.71 & 0.51 \\
\hline Pulses and other cereals & 19.2 & -0.88 & 0.90 & 11.4 & -1.03 & 0.74 \\
\hline Animal products & 12.7 & -0.91 & 1.72 & 8.0 & -0.94 & 1.98 \\
\hline $\begin{array}{l}\text { Fruits, vegetables, and } \\
\text { root crops }\end{array}$ & 11.7 & -0.99 & 1.22 & 15.3 & -1.01 & 1.18 \\
\hline Other foods & 30.0 & -0.92 & 0.66 & 24.0 & -0.92 & 0.92 \\
\hline
\end{tabular}

SOURCES: The elasticities are based on Tafere et al. (2009); the budget shares are from the authors' calculations based on HICES (2004/05).

ties, and People's Region (SNNPR), where it accounts for the majority of food and calorie intake.

\section{Consumption Patterns across Rural-Urban Locations}

Part of the diversity of the consumption patterns throughout Ethiopia can be explained by the rural-urban livelihood dichotomy highlighted earlier. Urban consumption patterns are more dynamic than those in rural areas because urban consumption is highly monetized and sensitive to relative price and supply changes. Thus, comparison of the per capita budget shares, consumption quantities, costs, and calorie shares of major staples across rural and urban places of residence can provide insights into the differences in consumption patterns between these two environments. Moreover, given recent trends toward the increased urbanization of rural areas, such analysis may also offer insight into future consumption trends.

Table 7.3 shows the share of per capita consumption expenditures, quantities, and calories of the major foodgrains and enset, disaggregated by rural and urban places of residence. Overall, cereals make up a greater share of rural food expenditures (43 percent) than urban ( 27 percent). Teff alone constitutes 17 percent of urban food expenditures, while wheat, maize, and sorghum together constitute 29 percent of rural food expenditures. The urban food budget is dominated by expenditures on "other food items" (72 percent), including animal products, fruits, vegetables, and pulses. Although the share of the urban budget 


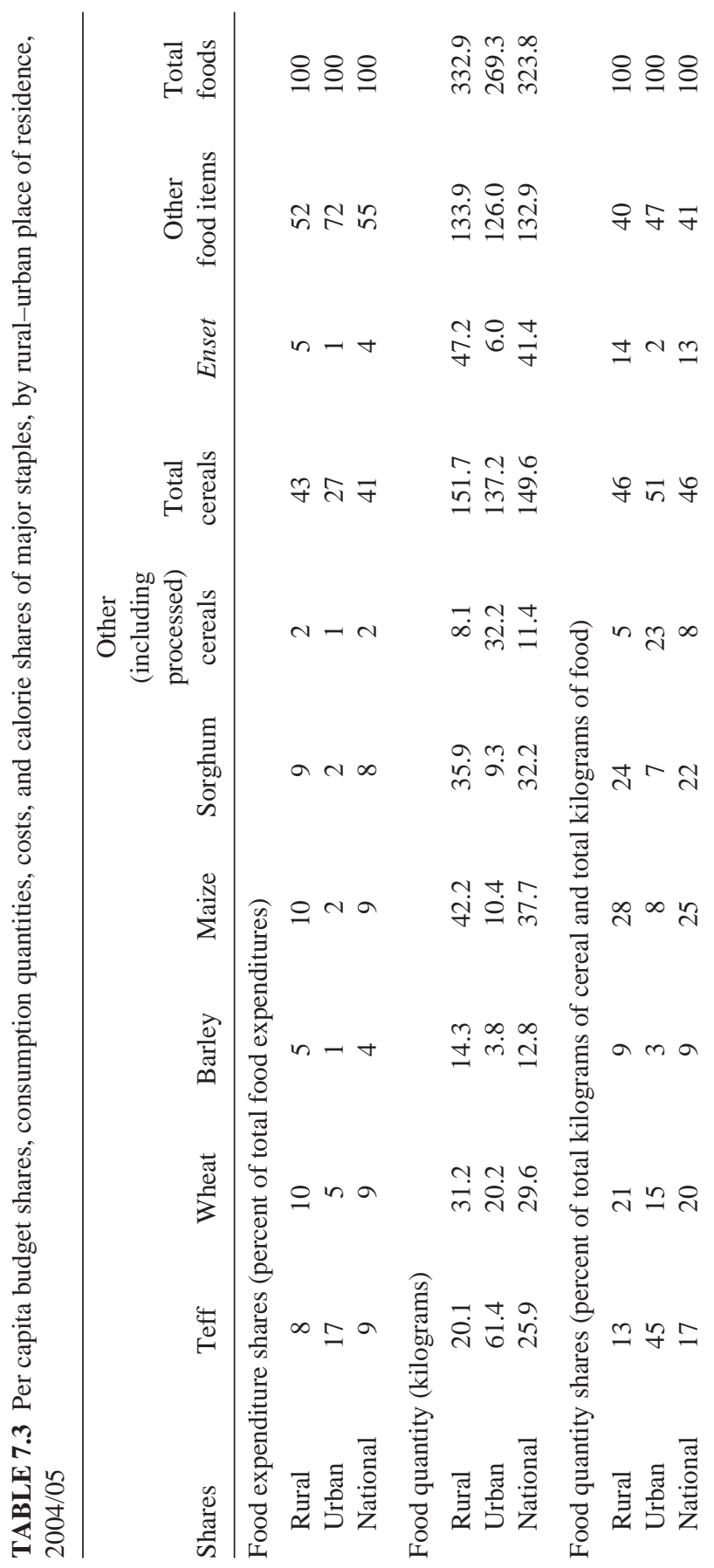




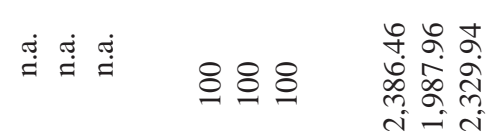

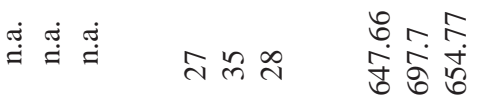

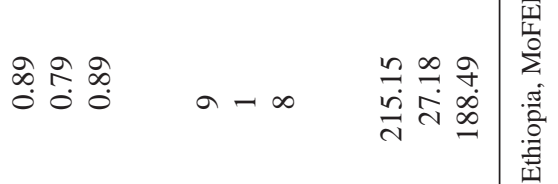

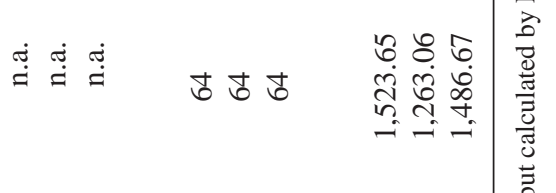

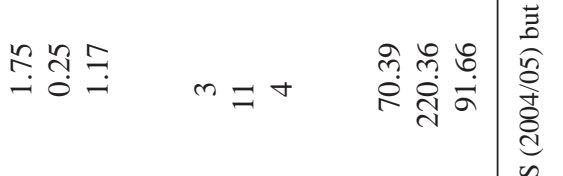

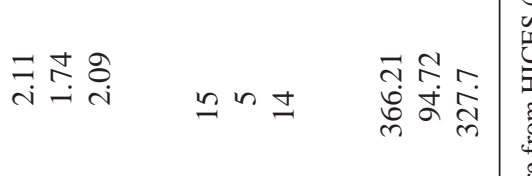

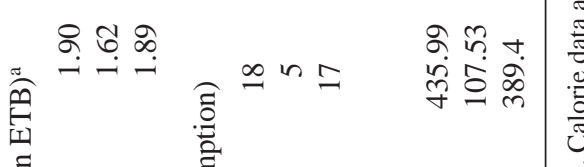

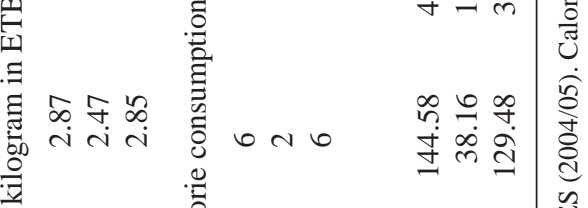

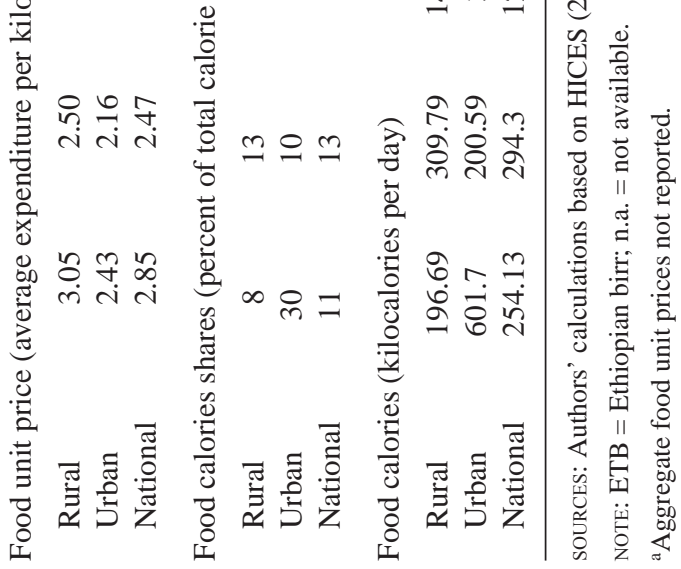


that is allocated to cereals is relatively low, the quantity share of cereal in the urban diet is 51 percent -5 percentage points higher than the rural and national shares. The source of this discrepancy between expenditure and quantity in the urban diet may be the relatively cheaper average unit prices of these cereals in urban areas than in rural ones. In every case, the urban average unit price is lower than the rural and national price for these staple goods (see Table 7.3). ${ }^{6}$

Consumption patterns differ not only across rural-urban locations but also across income groups in each area of residence. Figure 7.3 presents expenditure shares of major cereals in total food expenditures, disaggregated by the top 60 and bottom 40 percent of total food expenditures. This figure shows that the bottom 40 percent of rural income earners are among the largest consumers-in terms of budget share - of cereals in general and of maize, wheat, and sorghum in particular. Meanwhile, urban residents in the top 60 percent of total food expenditures are the smallest consumers of cereals. Note that the consumption share of cereals among urban residents in both income categories is much lower if processed cereals, which comprise a significant share of total food expenditures, are not included in the aggregation. It is also interesting to note that the top-earning 60 percent of rural residents consume, on average, relatively less total cereal than the bottom-earning 40 percent of urban residents. Overall, the lowest 40 percent of income earners-rural and urban combined-spend a greater share of their income on cereal than do the highest 60 percent of income earners; this pattern further indicates that expenditure shares of cereals decline as income increases.

Closer examination of individual cereals within income groups across rural and urban places of residence (Table 7.4) shows that teff is an urban staple regardless of income level. Meanwhile, expenditure shares of wheat, maize, sorghum, and enset remain relatively consistent in rural areas across both income groups. These data indicate clear differences in consumption trends between rural and urban diets that we might expect to continue with the continued urbanization of Ethiopia.

\section{Consumption Patterns across Agroecological Zones}

Based on moisture levels and livelihood patterns, Ethiopia's landscape can be classified into the following categories: humid agricultural highlands (further classified as cereal- and enset-growing areas), humid lowlands, arid and droughtprone areas, pastoralist lowlands, and densely populated urban areas (see Chapter 2 for more information). The 2004/05 HICES dataset shows considerable varia-

6. The extent of the discrepancy between the average urban and rural unit prices is surprising. As is discussed later, several food-deficit regions throughout Ethiopia import these key cereals from food-surplus regions. The significant difference in prices in the rural and urban areas implies that the cost of importing these cereals from food-surplus areas to food-deficit rural areas is, on average, greater than the cost of importing them to urban areas. 
FIGURE 7.3 Share of major cereals in total food expenditures in Ethiopia, by income group and rural-urban place of residence, 2004/05

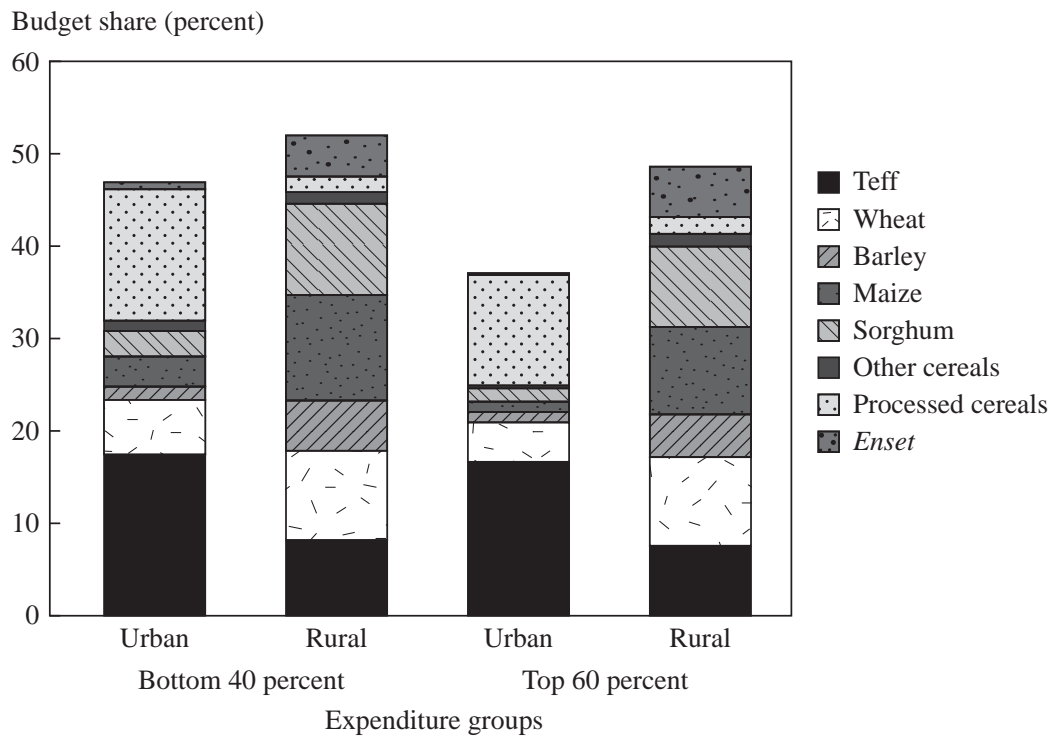

SOURCE: Authors' calculations based on HICES (2004/05).

TABLE 7.4 Share of major cereals in total food expenditures, by income group and rural-urban place of residence, 2004/05 (percent)

\begin{tabular}{lrrrrr}
\hline & \multicolumn{2}{c}{ Bottom 40} & & \multicolumn{2}{c}{ Top 60 } \\
\cline { 2 - 3 } \cline { 5 - 6 } Cereal & Urban & Rural & & Urban & Rural \\
\hline Teff & 17.3 & 7.9 & & 16.4 & 7.3 \\
Wheat & 6.0 & 9.8 & & 4.3 & 9.5 \\
Barley & 1.3 & 5.5 & & 0.9 & 4.7 \\
Maize & 3.2 & 11.1 & & 1.2 & 9.1 \\
Sorghum & 2.7 & 9.9 & & 1.3 & 8.9 \\
Other cereals & 1.2 & 1.7 & & 0.7 & 1.7 \\
Processed cereals & 14.3 & 1.3 & & 11.6 & 1.6 \\
Total cereals & 46.0 & 47.3 & & 36.4 & 43 \\
Enset & 0.9 & 4.4 & & 0.3 & 5.5 \\
\hline
\end{tabular}

SOURCE: Authors' calculations based on HICES (2004/05). 
tion in consumption patterns across these agroecological zones. A snapshot of this variation is offered in Table 7.5, which presents per capita consumption shares of the total quantity of staple foods consumed by agroecology.

Generally, except in enset-growing areas, the five major cereals and their processed products account for more than 50 percent of the total quantity of food consumed in Ethiopia. The greatest consumption of cereal grains in the country is found in the pastoralist areas, where, followed by wheat and maize, the greatest quantities of sorghum are consumed, comprising 23 percent of total food expenditures. Traditionally, the lowland areas are known for growing maize and sorghum, while wheat is grown in the areas of the country that lie between 1,500 and 2,500 meters above sea level (EEA 2004). The high levels of wheat consumption in the lowland pastoralist areas may thus be due in part to food aid distribution in recent years.

The cereal-growing humid (rural) highlands and large cities are the secondgreatest consumers of cereal grains, followed by the drought-prone areas. The three main cereal grains, teff, wheat, and maize, account for 36 percent of total food consumption in the humid cereal-growing highlands. Teff is the most important staple in urban Ethiopia, where injera is eaten at almost every meal. Sorghum and maize dominate food consumption in the humid lowlands (accounting for 16 percent each of total food consumption) and drought-prone areas (accounting for 17 percent and 13 percent of total food consumption, respectively). Enset, a root crop that grows predominantly in the humid high-

TABLE 7.5 Per capita share of the total quantity of cereals and enset consumed, by agroecological zone and rural-urban place of residence, 2004/05 (percent)

\begin{tabular}{|c|c|c|c|c|c|c|c|}
\hline \multirow[b]{3}{*}{ Cereal } & \multicolumn{5}{|c|}{ Rural } & \multirow{2}{*}{\multicolumn{2}{|c|}{ Urban }} \\
\hline & & Humid & Humid & & & & \\
\hline & $\begin{array}{l}\text { Humid } \\
\text { lowlands }\end{array}$ & $\begin{array}{l}\text { growing } \\
\text { highlands }\end{array}$ & $\begin{array}{l}\text { growing } \\
\text { highlands }\end{array}$ & $\begin{array}{l}\text { prone } \\
\text { areas }\end{array}$ & $\begin{array}{c}\text { Pastoralist } \\
\text { areas }\end{array}$ & $\begin{array}{l}\text { Small } \\
\text { cities }\end{array}$ & $\begin{array}{l}\text { Large } \\
\text { cities }\end{array}$ \\
\hline Teff & 1.0 & 11.0 & 1.0 & 4.0 & 2.0 & 19.0 & 29.0 \\
\hline Wheat & 1.0 & 12.0 & 4.0 & 11.0 & 20.0 & 9.0 & 6.0 \\
\hline Barley & 1.0 & 6.0 & 1.0 & 5.0 & 0.0 & 2.0 & 1.0 \\
\hline Maize & 16.0 & 13.0 & 12.0 & 13.0 & 15.0 & 5.0 & 1.0 \\
\hline Sorghum & 16.0 & 9.0 & 6.0 & 17.0 & 23.0 & 5.0 & 1.0 \\
\hline $\begin{array}{l}\text { Other (including } \\
\text { processed) } \\
\text { cereals }\end{array}$ & 1.0 & 4.0 & 1.0 & 2.0 & 3.0 & 10.0 & 15.0 \\
\hline Total cereals & 36.0 & 55.0 & 25.0 & 52.0 & 63.0 & 50.0 & 53.0 \\
\hline Enset & 21.0 & 6.0 & 29.0 & 12.0 & 0.0 & 4.0 & 0.0 \\
\hline
\end{tabular}

SOURCE: Authors' calculations based on HICES (2004/05).

Note: Large cities are Addis Ababa, Dire Dawa, and Harare; all other cities are categorized as small. 
lands of the SNNPR and associated humid lowlands, is a major staple in those areas. Consequently, the humid enset-growing highlands have the lowest cereal consumption in per capita terms.

\section{Consumption Patterns across Administrative Regions}

Substantial variation in consumption patterns is also observed across administrative regions throughout Ethiopia. This variation hints at differences in ethnocultural preferences across the country as well as substantial interregional trade and price differentials. It also allows us to classify regions in terms of food sufficiency and calorie consumption.

Boundaries of the major regions in Ethiopia have been drawn largely on the basis of ethnicity; therefore, observation of consumption shares across those regions offers insight into ethnocultural preferences. Table 7.6 presents the shares of the five major cereals plus enset in households' total food expenditures, disaggregated by administrative region. The 2004/05 HICES data show substantial interregional variation. In general, Tigray allocates more than half of its food budget to cereal. Amhara, Dire Dawa, and Oromiya follow Tigray in allocating, respectively, 49.3, 45.3, and 45.0 percent of total food expenditures to the five major cereals. Teff accounts for the largest share of regional food expenditure in Amhara and Tigray regions; Addis Ababa is the highest consumer of this grain nationally. Wheat accounts for approximately 10 percent of the food budget in many regions, including Tigray, Amhara, Oromiya, Somali, and Afar; these regions are also among the largest food aid recipients of wheat in the country. In line with earlier findings, the expenditure share of processed cereals (and other cereals) is highest in the urban regions of Dire Dawa, Addis Ababa, and Harari. Overall, in addition to the urban regions, the lowland regions of Afar, Somali, Harari, and especially the SNNPR have the lowest consumption of cereals in Ethiopia. The SNNPR consumes more enset than any other region, while the food budgets in Afar, Somali, and Harari are concentrated on other food items, such as animal products and pulses.

Regional consumption patterns generally follow regional specialization in production. However, this is not the case for all grains. For example, in 2003/ 04, Oromiya was reported as the highest teff producer, in terms of both total and per capita production, after Amhara region (EEA 2004, 56). However, Oromiya's share of consumption expenditure on teff was 8 percent, a little less than the share of its expenditure on maize and wheat. In direct contrast, Afar, a region known in Ethiopia for its limited teff production potential, allocated higher budget shares to teff (10 percent) than did Oromiya. This indicates that there is substantial interregional trade in these grains as well as price differentials among regions. Meanwhile, consistent with its production potential, Benishangul-Gumuz is the highest consumer of sorghum in the country, followed by Tigray, which also has a great deal of sorghum production potential in its western lowlands. 


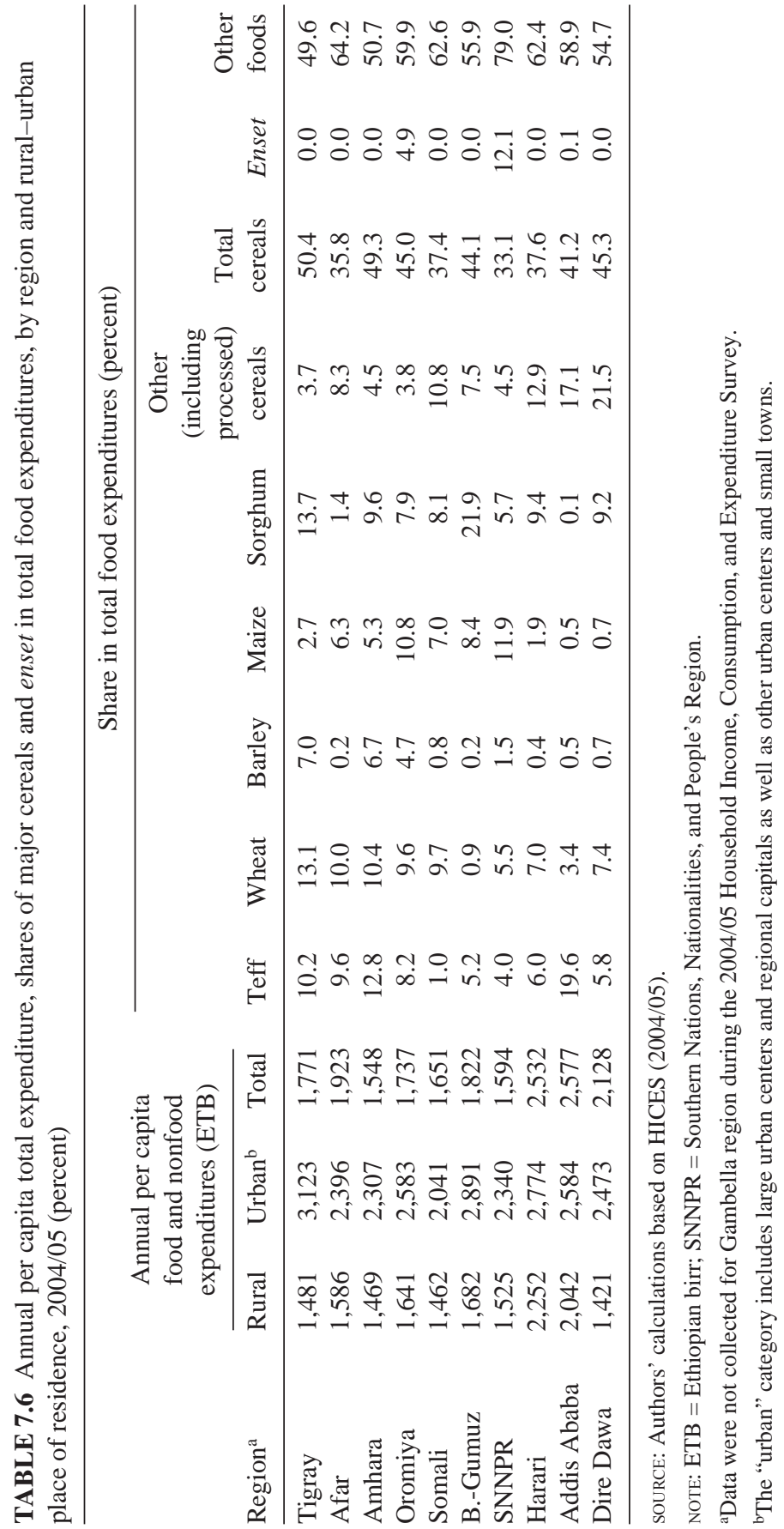


The geography of food availability in Ethiopia can be classified into fooddeficit areas, food-balanced areas, and food-surplus areas (Diao and Pratt 2007). Food-deficit woredas are those with cereal-equivalent output per rural household at levels 20 percent below the national average, food-balanced woredas are those with cereal-equivalent output at levels 80-120 percent of the national average, and food-surplus woredas are those with cereal-equivalent output at levels 20 percent greater than the national average. Based on the 2001/02 Agricultural Census Survey of Ethiopia, about 26 million Ethiopians (50 percent of the rural poor or 37 percent of the total rural population) live in food-deficit areas, where the average annual food availability, 530 kilograms per household, is only half the national average. In contrast, food availability in the foodsurplus areas averages 1,800 kilograms per household, about 70 percent over the national average. Such disparities in food availability lead to differences in calorie consumption across regions and agroecologies (Diao and Pratt 2007).

A disaggregated analysis of the extent of calorie consumption by place of residence, agroecology, region, and income presents a better picture of the national food consumption pattern. Table 7.7 presents the daily per adult equivalent calorie intake in 2004/05 by region, while Table 7.8 disaggregates caloric intake and expenditures by income quintile, agroecology, and place of residence.

Compared with other regions, SNNPR has the highest total per adult equivalent calorie intake as well as the lowest expenditure per calorie consumed. The high-calorie-low-cost consumption pattern in SNNPR is largely due to the regional reliance on enset. Oromiya closely follows SNNPR with high per adult calorie consumption and relatively low cost per calorie. It should also be noted

TABLE 7.7 Calories consumed and the cost of calories, by region 2004/05

\begin{tabular}{lcccc}
\hline Region & $\begin{array}{c}\text { Annual per capita } \\
\text { expenditure on } \\
\text { cereals and } \text { enset } \\
\text { (millions) }\end{array}$ & $\begin{array}{c}\text { Total calories } \\
\text { per adult } \\
\text { equivalent, } \\
\text { per day }\end{array}$ & $\begin{array}{c}\text { Cost per 1,000 } \\
\text { calories (ETB) }\end{array}$ \\
\hline Tigray & 4.2 & 387.9 & 2,619 & 1.00 \\
Afar & 0.2 & 317.5 & 2,548 & 1.16 \\
Amhara & 16.7 & 385.3 & 2,638 & 1.00 \\
Oromiya & 25.7 & 445.1 & 3,103 & 1.00 \\
Somale & 0.7 & 328.6 & 2,706 & 1.11 \\
B.-Gumuz & 0.8 & 403.4 & 2,684 & 1.15 \\
SNNPR & 13.5 & 344.7 & 3,155 & 0.83 \\
Harari & 0.2 & 404.6 & 2,768 & 1.31 \\
Addis Ababa & 2.4 & 336.7 & 2,157 & 1.17 \\
Dire Dawa & 0.3 & 427.4 & 2,437 & 1.26 \\
\hline
\end{tabular}

SOURCE: Authors' calculations based on HICES (2004/05).

NOTE: ETB = Ethiopian birr; SNNPR = Southern Nations, Nationalities, and People's Region. 
TABLE 7.8 Calories consumed and the cost of calories, by income quintile, agroecological zone, and rural-urban residence, 2004/05

\begin{tabular}{|c|c|c|c|c|}
\hline & $\begin{array}{c}\text { Population } \\
\text { (millions) }\end{array}$ & $\begin{array}{c}\text { Annual } \\
\text { per capita } \\
\text { expenditure } \\
\text { on cereals } \\
\text { and } \text { enset } \\
\text { (ETB) }\end{array}$ & $\begin{array}{c}\text { Total calories } \\
\text { per adult } \\
\text { equivalent, } \\
\text { per day }\end{array}$ & $\begin{array}{c}\text { Cost per } \\
1000 \text { calories } \\
\text { (ETB) }\end{array}$ \\
\hline National & 64.5 & 398.6 & 2,907 & 1.00 \\
\hline \multicolumn{5}{|l|}{ Income quintile } \\
\hline Quintile 1 & 16.8 & 318.4 & 1,948 & 1.10 \\
\hline Quintile 2 & 14.8 & 372.5 & 2,707 & 0.97 \\
\hline Quintile 3 & 13.0 & 422.7 & 3,273 & 0.89 \\
\hline Quintile 4 & 11.3 & 432.6 & 3,480 & 0.87 \\
\hline Quintile 5 & 8.5 & 449.7 & 3,716 & 0.88 \\
\hline \multicolumn{5}{|l|}{ Agro-ecological zones } \\
\hline Humid lowland & 0.9 & 368.9 & 2,857 & 0.90 \\
\hline Humid highland (cereals) & 29.6 & 414.8 & 2,813 & 1.02 \\
\hline Humid highland (enset) & 12.0 & 344.3 & 3,198 & 0.84 \\
\hline Drought prone & 21.0 & 409.2 & 2,890 & 0.99 \\
\hline Pastoralist areas & 1.0 & 374.1 & 2,632 & 1.17 \\
\hline \multicolumn{5}{|l|}{ Urban-rural } \\
\hline Urban & 9.1 & 360.713 & 2,340 & 1.23 \\
\hline Rural & 55.3 & 404.817 & 3,007 & 0.94 \\
\hline
\end{tabular}

SOURCE: Authors' calculations based on HICES (2004/05, n. 12).

NOTES: The calorie conversion units are obtained from the Ethiopian Health and Nutrition Research Institute (EHNRI). Schmidt and Dorosh (2009) compared these conversion units against Food and Agriculture Organization conversion factors and found little variation between them. Note, however, that because the Household Income, Consumption, and Expenditure Survey (HICES) dataset contains household-level data, the calories reported here are computed by aggregating food items into 18 categories and taking the average calorie conversion units for each category of foods consumed by each household. Our estimates, although crude, are close to the estimates of Ethiopia, CSA (2007). ETB = Ethiopian birr.

that the SNNPR and Oromiya are home to 61 percent of Ethiopia's total population. In contrast, the regions dominated by urban cities, such as Addis Ababa, Dire Dawa, and Harari, have the lowest per capita calorie intake. In fact, overall, rural areas have higher calorie intake than do urban areas. This may be due to the fact that rural dwellers' consumption of maize and sorghum is much higher than that of urban residents, whose food consumption patterns are more concentrated on teff, a more expensive crop that offers fewer calories per gram than sorghum or maize. The cost per calorie of food consumed in urban areas is also greater than that in other regions. 
Similar to the way that calorie intake varies regionally, it also varies by agroecology, with the humid enset-producing highlands recording the highest level of calorie intake per day. In 2004/05, per adult equivalent calorie intake is second highest in the drought-prone areas of the country, though it should be noted that 2004/05 was a year of good rainfall and cereal harvests. Among agroecological zones, the pastoralist areas have the lowest levels of calorie intake per day; however, the average urban household consumes even fewer calories than the average rural household, regardless of agroecological zone. The level of calorie intake improves significantly, though at a decreasing rate, with the economic status of the households. For instance, households in the second income quintile have per adult equivalent calorie intake levels that were greater by 39 percent than those of the households in the lowest quintile, while households in the fourth quintile have caloric intake levels only 6 percent greater than those in the third quintile.

\section{Rural Consumption by Livelihood}

A closer look at consumption patterns among the rural populations of Ethiopia can be attained by disaggregation of households by livelihood: agropastoral, pastoral, and cropping households. The majority of agropastoral households are found in Oromiya (which has 44 percent of the total agropastoral population), Somali (34 percent), and the SNNPR (13 percent), while pastoral households are found predominantly in Somali (which has 59 percent of the total pastoral population), Afar (28 percent), and Oromiya (13 percent). The remaining rural population is dominated by cropping households, which make up 90 percent of the total rural population and are concentrated in Oromiya, Amhara, the SNNPR, and Tigray. See Figures 7.4, 7.5, and 7.6 for breakdowns of livelihood groups by region.

Among the cropping, agropastoral, and pastoral households we see significant differences in reliance on own production, the market, and aid for food consumption (Table 7.9). Overall, cropping households consume over 75 percent of their calories from their own crops, meat, and dairy production and have the lowest reliance on food aid and gifts among rural households. However, relative reliance on own production, the market, and aid differs by region. Cropping households in the less populous regions of Tigray, Somali, Gambella, and Benishangul-Gumuz have greater reliance on aid and gifts than do those in the more populous regions. Meanwhile, agropastoral households consume over 66 percent of their calories from their own crop $(50.3$ percent), meat, and dairy (16.2 percent) production; however, households in Somali region consume substantially more from their own meat and milk production (22 percent) than do those in Oromiya (10.5 percent) and Afar (15.4 percent). The agropastoral households in the less populated Afar region are more reliant on food aid for food consumption, while those in Somali 
FIGURE 7.4 Distribution of rural population, by region and livelihood, 2008

Rural population (percent)

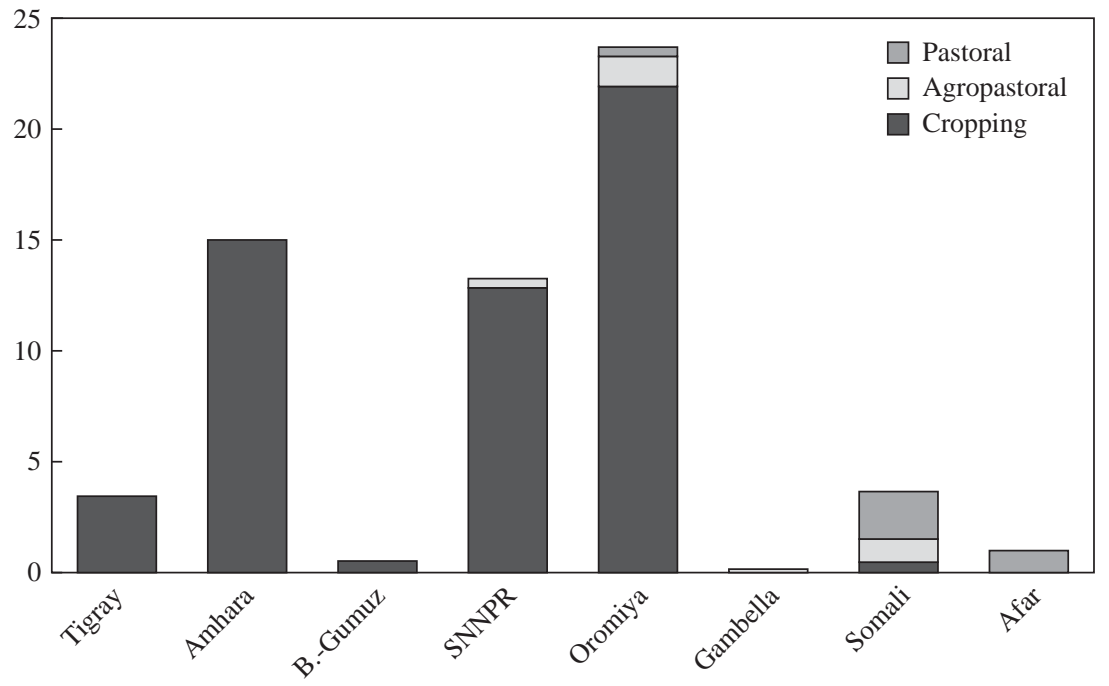

SOURCE: Authors' calculations based on LIU (2008).

NOTE: SNNPR = Southern Nations, Nationalities, and People's Region.

FIGURE 7.5 Ethiopia's rural agropastoral population, by region, 2008

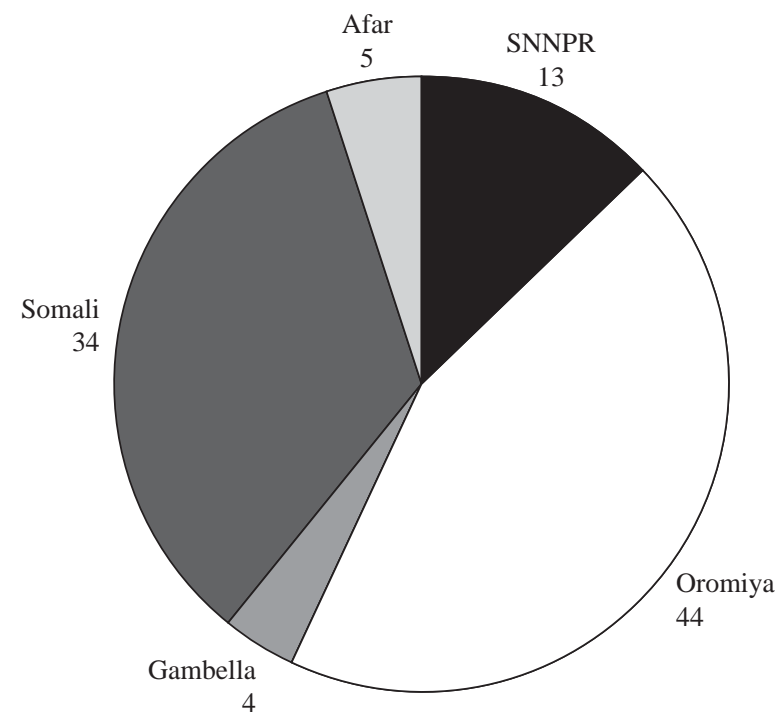

SOURCE: Authors' calculations based on LIU (2008).

NOTES: The estimated total rural agropastoral population is 2.93 million. SNNPR = Southern Nations, Nationalities, and People's Region. 
FIGURE 7.6 Ethiopia's rural pastoral population, by region, 2008

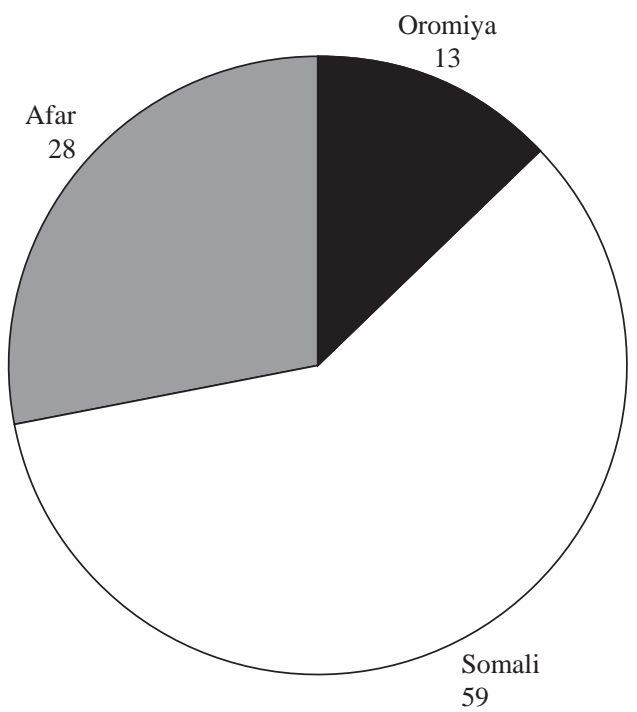

SOURCE: Authors' calculations based on LIU (2008).

NOTE: The estimated total rural pastoral population is 3.71 million.

region draw more on gifts than do the other regions. Pastoral households, lacking crop production, are heavily reliant on their own milk and meat production (38.4 percent overall) and purchases (55.3 percent). In addition, pastoralists in Afar region derive a relatively large proportion (18.6 percent) of their total calorie consumption from food aid.

Restriction of the data to rural households classified as poor and very poor (Table 7.10) shows that these groups have an even greater reliance on the market (as high as 72.5 percent among pastoralists in Oromiya), food aid, and gifts. Poor and very poor agropastoralists consume fewer calories from either source of own production (crops or milk and meat) than do nonpoor households in the same livelihood category, and an even greater reduction in consumption of own production is observed among the poor and very poor pastoralists relative to nonpoor households in the same livelihood category.

Overall, the values in Tables 7.9 and 7.10 paint a picture of vulnerability as well as resilience. Reliance on markets can be a source of vulnerability in the case of price rises or market failures. Reliance on households' own production can be a source of vulnerability in the cases of crop failures, droughts, pests, livestock diseases, and so on. And reliance on food aid and gifts is evidence of such failures in the past. However, the diversity of sources of food observed 


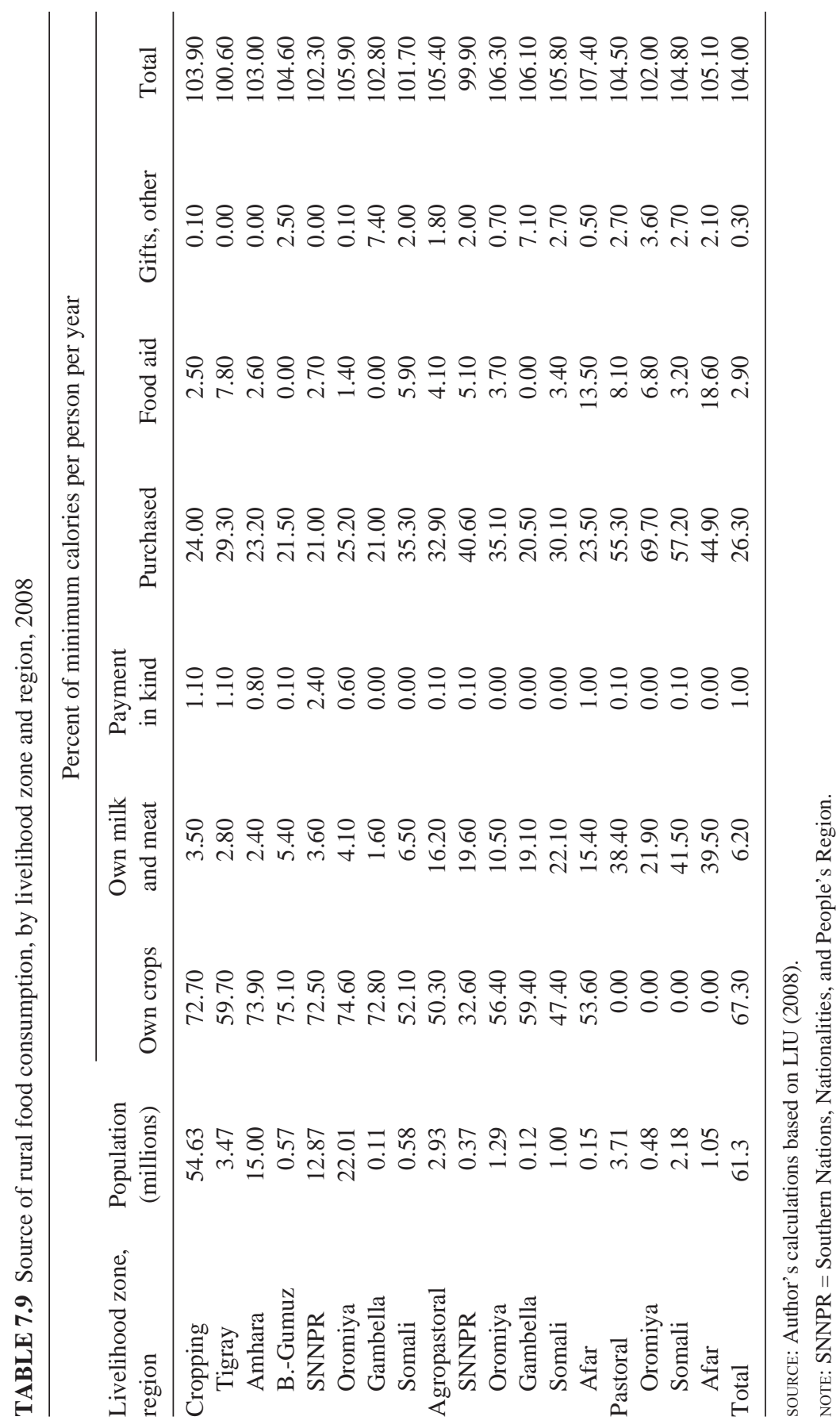




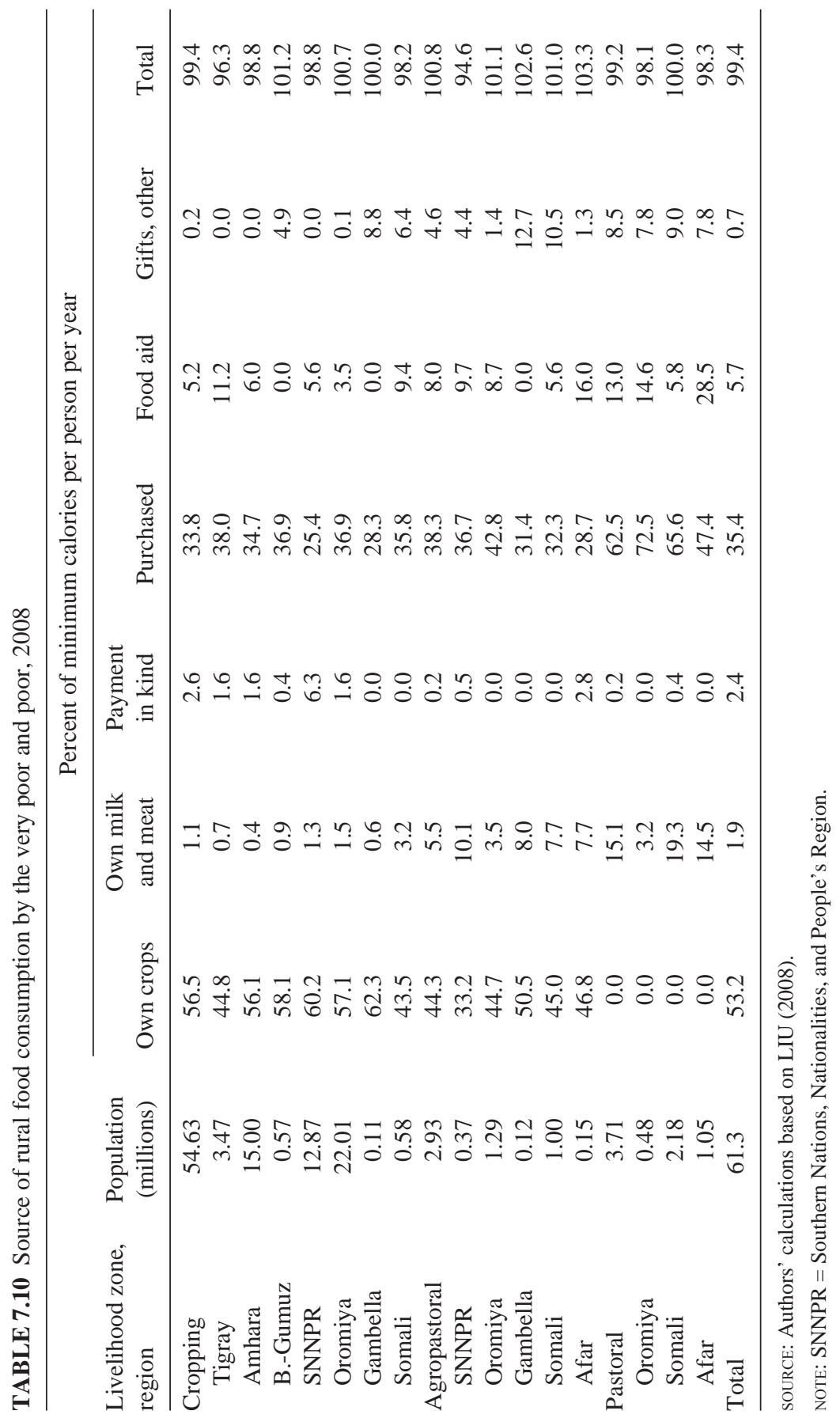


here points to rural households' resilience and ability to adapt in the case of failure of any one source.

\section{Temporal Trends in Consumption}

Spatial analysis of food consumption in Ethiopia has offered insight into demand, consumption, and food security patterns by place of residence, region, agroecology, income, and livelihood. Analysis of changes in consumption patterns over time offers insight into recent trends in demand, consumption, and food security across the country.

Drawing on data from the last three HICES (1994/95, 1999/2000, and 2004/05), Figure 7.7 presents the shares in household expenditures of the five major cereal grains for which disaggregated data are available (in addition to the category "other cereals") across the three available data points. The figure shows that the share of cereal grains in total consumption expenditures fell, then rose, over the data points considered. However, the trends for individual cereal grains varied substantially. Specifically, the share of teff declined between 1999/2000 and 2004/05, while shares of maize, sorghum, barley, and wheat rose over the same period. Overall, these trends (1999/2000-2004/05) show a shift toward greater allocation of household food budgets to the lower-cost, higher-calorie grains (maize, sorghum, barley, and wheat) and away from the lower-calorie, higher-cost grain (teff).

Note that Figure 7.7 is based on national average consumption shares over time and therefore masks differences across income groups. Figure 7.8 therefore disaggregates these trends by income quintiles; these data confirm the finding reported earlier - that households, even among the wealthiest quintile, have shifted away from teff expenditures toward expenditures on other grains.

Also, as seen earlier and consistent with the Engel curve, cereal consumption declined from the first to the fifth quintile, while the role of teff as an income-elastic luxury good among wealthy households was evident in the 1999/ 2000 and 1994/95 survey years. Barley took the lowest share of the household budget across all years and income quintiles.

The available data on calorie consumption across time confirm that rising incomes, as well as the shift toward expenditures on higher-calorie staples, have resulted in greater caloric intake. At the national level, there was a remarkable increase (about 40 percent) in calorie consumption across the period 1994/952004/05 (Table 7.11). However, the increase varied by place of residence and region. The percentage of change from 1994/95 to 2004/05 shows that there was an increase in calorie intake in every region except urban Afar. The greatest increases were observed in the SNNPR (with a 61 percent increase in per capita calorie consumption) and Benishangul-Gumuz (45 percent). Overall, calorie consumption rose by 44 percent in rural and 16 percent in urban areas.

These trends imply that there is increasing consumption and food security throughout the country over time. Indeed, other analyses confirm these implica- 
FIGURE 7.7 Share of major cereals in total food expenditures, 1994/95, 1999/2000, and 2004/05

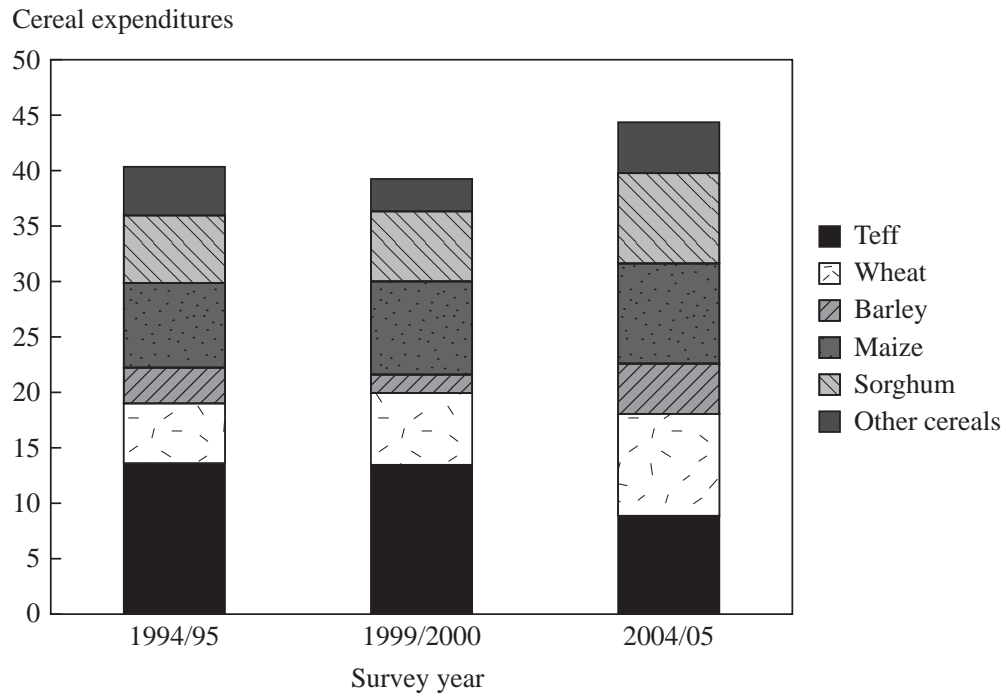

SOURCE: Authors' calculations based on HICES (2004/05).

FIGURE 7.8 Share of major cereals in total food expenditures across income quintiles, 1994/95, 1999/2000, and 2004/05

Percent

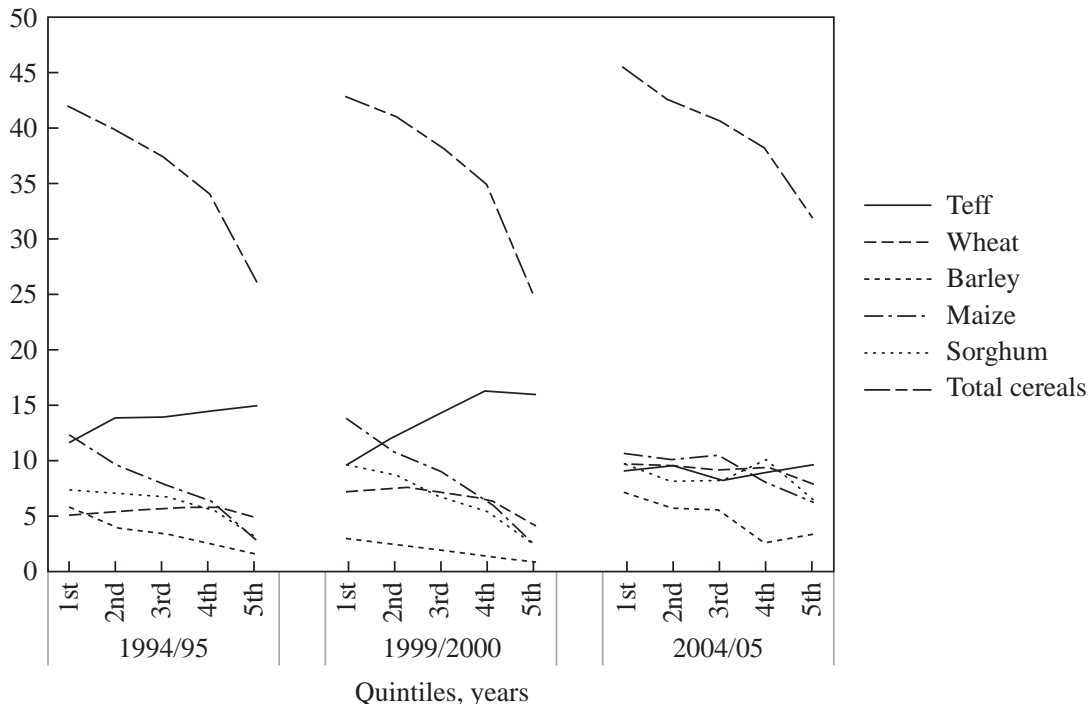

SOURCE: Authors' calculations based on HICES (2004/05). 


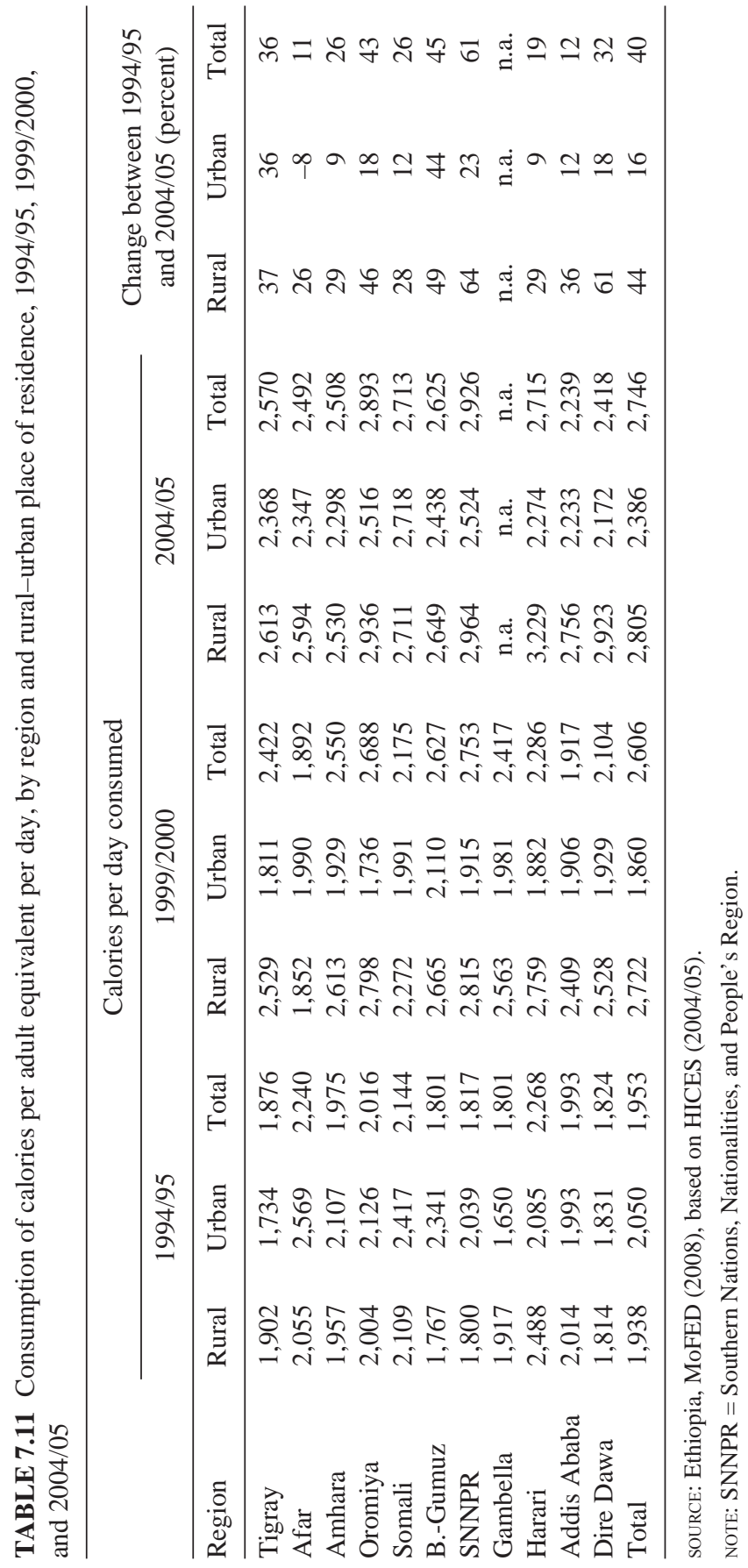


TABLE 7.12 Ethiopia Regional Hunger Index and underlying components, by region and rural-urban place of residence, 2000 and 2005

\begin{tabular}{|c|c|c|c|c|c|c|c|c|}
\hline \multirow{2}{*}{$\begin{array}{l}\text { Place of residence, } \\
\text { region }\end{array}$} & \multicolumn{2}{|c|}{$\begin{array}{c}\text { Prevalence of } \\
\text { calorie } \\
\text { undernourishment } \\
\text { (percent) }\end{array}$} & \multicolumn{2}{|c|}{$\begin{array}{l}\text { Prevalence of } \\
\text { underweight } \\
\text { among children } \\
\text { under } 5 \text { years } \\
\text { (percent) }\end{array}$} & \multicolumn{2}{|c|}{$\begin{array}{l}\text { Under-5 } \\
\text { mortality rate } \\
\text { (percent) }\end{array}$} & \multicolumn{2}{|c|}{$\begin{array}{c}\text { Regional } \\
\text { Hunger Index }\end{array}$} \\
\hline & 2000 & 2005 & 2000 & 2005 & 2000 & 2005 & 2000 & 2005 \\
\hline \multicolumn{9}{|c|}{ Rural-urban place of residence } \\
\hline Large urban & 73.5 & 53.1 & 16.0 & 12.8 & 12.1 & 7.8 & 33.5 & 24.6 \\
\hline Small urban & 85.4 & 51.9 & 41.4 & 27.1 & 16.1 & 10.6 & 47.6 & 29.9 \\
\hline Rural & 63.4 & 45.0 & 48.5 & 39.5 & 19.0 & 13.3 & 43.6 & 32.6 \\
\hline \multicolumn{9}{|l|}{ Region } \\
\hline Addis Ababa & 72.9 & 53.3 & 14.1 & 11.0 & 11.4 & 7.2 & 32.8 & 23.8 \\
\hline Harari & 65.2 & 47.6 & 27.1 & 26.7 & 19.1 & 10.3 & 37.1 & 28.2 \\
\hline Oromiya & 61.1 & 42.3 & 42.4 & 34.4 & 19.4 & 12.2 & 41.0 & 29.6 \\
\hline SNNPR & 77.6 & 45.5 & 53.7 & 34.7 & 19.2 & 14.2 & 50.1 & 31.5 \\
\hline Dire Dawa & 68.5 & 51.3 & 30.8 & 29.6 & 17.6 & 13.6 & 39.0 & 31.5 \\
\hline Amhara & 60.3 & 47.1 & 51.8 & 48.9 & 18.3 & 15.4 & 43.5 & 37.1 \\
\hline Tigray & 72.6 & 59.3 & 47.9 & 41.9 & 16.9 & 10.6 & 45.8 & 37.3 \\
\hline B.-Gumuz & 60.1 & 53.6 & 42.3 & 44.6 & 19.8 & 15.7 & 40.7 & 38.0 \\
\hline Ethiopia & 65.9 & 46.0 & 47.2 & 38.4 & 18.8 & 13.2 & 43.9 & 32.5 \\
\hline
\end{tabular}

SOURCE: Replicated from Schmidt and Dorosh (2009); the authors used data from HICES (1999/2000, 2004/05) and EDHS (1999/2000, 2004/05).

NOTE: SNNPR = Southern Nations, Nationalities, and People's Region.

tions (Table 7.12). In particular, the Ethiopia Regional Hunger Index (ERHI) (Schmidt and Dorosh 2009), which draws on the HICES as well as the Ethiopia Demographic and Health Surveys for 1999-2000 and 2004-05, shows that hunger, as measured by the proportion of undernourished adults, the proportion of underweight children, and the child mortality rate, declined across the country between 1999 and 2005 by 26 percent (from 43.9 to 32.5). The effect was greater in urban than in rural areas: in small urban areas the index fell from 47.6 to 29.9 , and in large urban areas it fell from 33.5 to 24.6 , while in rural areas it fell from 43.6 to $32.6^{7}$

Regionally, the greatest reductions in hunger were observed in the SNNPR, which showed a 37 percent reduction, from 50.1 to 31.5 , and Oromiya, with a 28 percent reduction, from 41.0 to 29.6 . However, it is important to note that, despite these dramatic reductions in hunger, all regions in Ethiopia—both rural

7. The ERHI data cover six of the nine administration regions of Ethiopia. The data do not include Gambella or the nonsedentary populations of Afar and Somali. 


\section{Guush Berhane et al.}

and urban - have very high values for the hunger index. Using the cutoffs from the Global Hunger Index (von Grebmer et al. 2010), all of Ethiopia falls into the "alarming" (20.0-29.9) or the "extremely alarming" (greater than 30.0) category (Figure 7.9). In fact, the smallest reductions in hunger were observed in the regions with hunger indexes categorized as "most alarming" according to the Global Hunger Index cutoffs: Benishangul-Gumuz (ERHI of 38.0), Tigray (37.3), and Amhara (37.1).

\section{Conclusions}

The wide diversity in consumption patterns across regions and the tendency of nearly all household groups to consume a variety of cereals (as well as enset, especially in the SNNPR), reduces reliance on a single staple and thereby reduces the risks associated with the failure of a single crop. For pastoralists and agropastoralists in dry lowland parts of Ethiopia, livestock products (including dairy) are a major source of calories and incomes, but both poor and nonpoor households purchase a large share of their food.

FIGURE 7.9 Ethiopia Regional Hunger Index, 2005

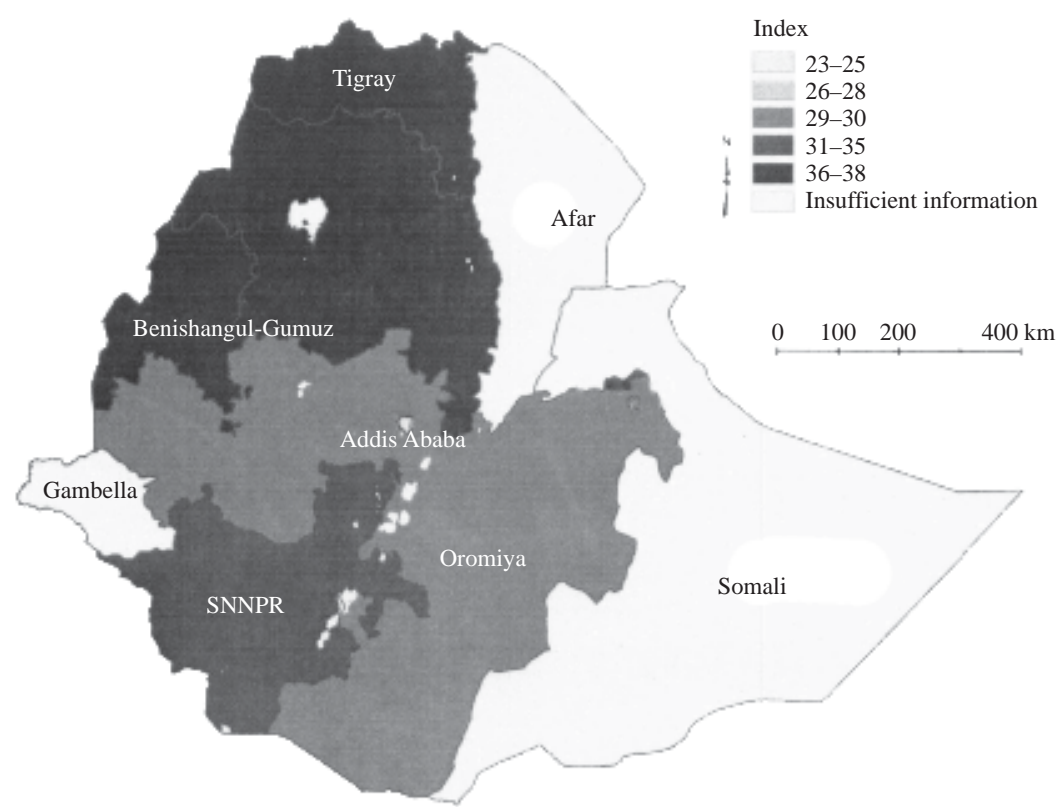

SOURCE: Schmidt and Dorosh (2009).

NOTE: SNNPR = Southern Nations, Nationalities, and People's Region. 
Overall, calorie consumption and food security across Ethiopia have increased. Per capita intake of calories is higher in rural than in urban areas, because urban consumption is concentrated on teff, which has a lower calorie content. Additionally, among agroecological zones in rural areas, the pastoralist areas have the lowest calorie intake levels. The share of food expenditures in total expenditures remains fairly high but has declined over time and declines more dramatically in urban than in rural households with rising incomes. Although additional data are needed to ascertain the extent to which the trends observed here have continued since 2005, it is reasonable to expect that, as household incomes continue to grow, food security will continue to increase while the portion of money spent on food, and on cereals in particular, will continue to decline, consistent with the trends we have observed.

These consumption patterns have important implications for agricultural growth and development policies in Ethiopia. Specifically, without growth in the industrial sector, continued agricultural growth will not be sustained by domestic agricultural demand alone-especially with continued urbanization of the country.

\section{References}

Diao, X., and A. Nin Pratt. 2007. "Growth Options and Poverty Reduction in EthiopiaAn Economic Wide Model Analysis." Food Policy 32 (7): 205-228.

EDHS (Ethiopia Demographic and Health Survey). 1999/2000, 2004/05. Central Statistical Agency. Addis Ababa, Ethiopia.

EEA (Ethiopian Economic Association). 2004. Industrialization and Industrial Policy in Ethiopia: Report on the Ethiopian Economy, vol. 3, 2003/04. Addis Ababa, Ethiopia.

Ethiopia, CSA (Central Statistical Agency). 2007. Statistical Report, Household Income, Consumption, and Expenditure (HICE) Survey 2004/05, vol. 2, no. 394. Addis Ababa, Ethiopia.

Ethiopia, MoFED (Ministry of Finance and Economic Development). 2008. Dynamics of Growth and Poverty in Ethiopia. Addis Ababa, Ethiopia.

HICES (Household Income, Consumption, and Expenditure Survey). 1994/95, 1999/ 2000, 2004/05. Central Statistical Agency. Addis Ababa, Ethiopia.

LIU (Livelihoods Integration Unit). 2008. The Food Economy Group and Government of Ethiopia Disaster Prevention and Preparedness Agency. Addis Ababa, Ethiopia.

Negassa, A., and R. J. Myers. 2007. "Estimating Policy Effects on Spatial Market Efficiency: An Extension to the Parity Bounds Model." American Journal of Agricultural Economics 89 (2): 338-352.

Osborne, T. 2004. "Imperfect Competition in Agricultural Markets: Evidence from Ethiopia." Journal of Development Economics 76 (2005): 405-428.

Schmidt, E., and P. Dorosh. 2009. A Sub-national Hunger Index for Ethiopia: Assessing Progress in Region-Level Outcomes. Ethiopia Strategy Support Program II, 
Discussion Paper 5. Addis Ababa, Ethiopia: International Food Policy Research Institute.

Tafere, K., P. Zelekawork, A. S. Taffesse, T. Nigussie, and T. Seneshaw. 2009. Food Demand Elasticities in Ethiopia: Estimates Using 2004/05 Household Income, Consumption Expenditure (HICE) Survey Data. Ethiopia Strategy Support Program II, Discussion Paper 11. Addis Ababa, Ethiopia: International Food Policy Research Institute.

von Grebmer, K., M. T. Ruel, P. Menon, B. Nestorova, T. Olofinbiyi, H. Fritschel, Y. Yohannes, et al. 2010. Global Hunger Index 2010. Washington, DC: International Food Policy Research Institute. 